\title{
Hubungan Status Gizi dan Stimulasi Tumbuh Kembang dengan Perkembangan Balita
}

\author{
Mirham Nurul Hairunis, ${ }^{*}$ Harsono Salimo, ${ }^{* *}$ Yulia Lanti Retno Dewi* \\ ${ }^{*}$ Departemen Ilmu Gizi, ${ }^{* *}$ Departemen Ilmu Kesehatan Anak Fakultas Kedokeran Universitas Sebelas Maret/ Rumah Sakit Dr. \\ Moewardi, Surakarta
}

Latar belakang. Perkembangan dasar yang terjadi pada masa balita akan memengaruhi dan menentukan perkembangan anak selanjutnya. Status gizi dan stimulasi merupakan dua faktor yang memengaruhi tumbuh kembang balita.

Tujuan. Penelitian ini bertujuan menganalisis hubungan status gizi dan stimulasi tumbuh kembang dengan perkembangan anak Balita di Provinsi Nusa Tenggara Barat (NTB).

Metode. Jenis penelitian ini adalah studi penelitian analitik observasional dengan pendekatan cross-sectional. Penelitian ini dilaksanakan pada bulan Februari-April 2018. Sampel dipilih secara simple random sampling sebanyak 114 subjek penelitian. Teknik pengumpulan data menggunakan kuesioner dan dianalisis dengan regresi logistik.

Hasil. Berdasarkan hasil analisis multivariat antara status gizi $(\mathrm{TB} / \mathrm{U})$ dan stimulasi tumbuh kembang dengan perkembangan didapatkan hasil $(b=3,33$; IK95\%=7,46; $p=0,003)$ untuk status gizi dan $(b=3,10 ;$ IK95\%=1,25-7,65; $p=0,014)$ untuk stimulasi tumbuh kembang. Kesimpulan. Balita dengan perawakan normal memiliki peluang 3,3 kali mengalami perkembangan yang sesuai dibandingkan anak dengan perawakan pendek dan sangat pendek (stunting). Balita yang mendapatkan stimulasi tumbuh kembang sering memiliki peluang 3,1 kali mengalami perkembangan yang sesuai dibandingkan dengan anak yang mendapatkan stimulasi jarang. Sari Pediatri 2018;20(3):146-51

Kata kunci: perkembangan, stimulasi tumbuh kembang, status gizi

\section{The Correlation between Nutritional Status and Stimulation Growth and Development with The Development of Children Under Five Years}

Mirham Nurul Hairunis, ${ }^{*}$ Harsono Salimo, ${ }^{* *}$ Yulia Lanti Retno Dewi*

Background. Basic developments that occur during children under five years will influence and determine the child developments. Nutritional status and stimulation are two factors which influence children's growth and development.

Objective. To identify the correlation between stimulation growth and nutritional status with the development of children under five years.

Methods. This study was an analytic observational study with cross-sectional approach. This study was conducted in February-April 2018. Samples were children aged 12-60 months and parents as many as 114 children who live in Kabupaten Bima. Sampling technique in this study was using simple random sampling. The research instrument to assess development of children was prescreening development questionnaire KPSP form. Data were analyzed using chi-square, followed by multivariate analysis. The p-value $<0.05$ was considered as significant.

Result. Based on a result of multivariate analyzed between stimulation growth and nutritional status with the development of children under five years was nutritional status $(b=3.33$; IK95\% $=7.46 ; p=0.003)$ and stimulate growth and development dan $(b=3,10$; CI95\%:1.25-7.65; $\mathrm{p}=0.014)$.

Conclusion. Children under five years who had body height normal category have inappropriate development 3.3 times greater than children under five years who had stunting and severally stunting. Children under five years who had growth stimulation often have inappropriate 3.1 times greater than children under five years who had sparse stimulation. Sari Pediatri 2018;20(3):146-51

Keyword: development, growth development, nutritional status

Alamat korespondensi: Mirham Nurul Hairunis. Program Megister Nutrisi Uneversitas Sebelas Maret, Jl. Ir. Sutami No. 36 A, Surakarta, Indonesia. E-mail: mirhamnurul@gmail.com. 
$\mathrm{M}$ asa anak di bawah lima tahun merupakan periode penting dalam tumbuh kembang anak karena pertumbuhan dan perkembangan dasar yang berlangsung pada masa balita akan memengaruhi dan menentukan setiap perkembangan anak selanjutnya. ${ }^{1}$ Tumbuh kembang merupakan proses yang berkesinambungan yang terjadi secara konsepsi dan terus berlangsung hingga dewasa. ${ }^{2}$ Selain mengalami partumbuhan fisik yang pesat, perkembangan kemampuan otak juga penting untuk proses pembelajaran dan pengayaan perkembangan kecerdasan, keterampilan motorik, bicara dan bahasa, serta sosial dan kemandirian. ${ }^{3}$

Status gizi merupakan salah satu faktor yang dapat memengaruhi perkembangan anak. Beberapa faktor yang dapat memengaruhi perkembangan anak di negara berkembang, seperti kemiskinan, malnutrisi, sanitasi kesehatan yang buruk serta kurangnya stimulasi dari lingkungan. Anak dengan status gizi kurang akan mengalami perkembangan yang terhambat dan tidak optimal sesuai dengan tahapan usianya. ${ }^{4}$ Berdasarkan hasil riset kesehatan dasar (RISKESDAS) pada tahun 2013, prevalensi pendek (stunting) 37,2\% yang berarti terjadi peningkatan dibandingkan tahun 2010 (35,6\%) dan 2007 (36,8\%). Persentase tertinggi pada tahun 2013 adalah di Provinsi Nusa Tenggara Timur (51,7\%), Sulawesi Barat $(48,0 \%)$, dan Nusa Tenggara Barat $(45,3 \%) .^{5}$

Hasil pemantauan status gizi di Kabupaten Bima pada tahun 2016, prevalensi pendek (stunting) 36,7\%. Bila dibandingkan dengan batas "non public health problem" menurut WHO untuk masalah kependekan sebesar 20\% maka dari semua provinsi yang ada, termasuk Provinsi Nusa Tenggara Barat (NTB) masih dalam kondisi bermasalah terhadap kesehatan masyarakat, terutama masalah gizi. ${ }^{6}$ Terdapat 178 juta anak di dunia yang terlalu pendek berdasarkan usia dibandingkan dengan pertumbuhan standar WHO. Stunting menjadi indikator kunci dari kekurangan gizi kronis, seperti pertumbuhan yang melambat, perkembangan otak tertinggal sehingga anak stunting lebih mungkin mempunyai daya tangkap yang lebih rendah. $^{7}$

Rencana pembangunan jangka panjang daerah (RPJPD) Provinsi NTB 2005-2025 menetapkan 4 sasaran pembangunan kesehatan, yaitu meningkatkan umur harapan hidup menjadi 72 tahun, menurunkan angka kematian bayi menjadi 24 per 1000 kelahiran hidup, menurunkan angka kematian ibu menjadi
228 per 100 ribu kelahiran hidup, dan menurunkan prevalensi gizi kurang pada balita menjadi 15\% dan menurunkan prevalensi balita pendek menjadi 32\%.

Hasil deteksi dini tumbuh kembang yang dilakukan Departemen Kesehatan RI (2009) melaporkan 29\% keterlambatan perkembangan anak secara nasional pada tahun 2009. ${ }^{9}$ Keterlambatan perkembangan dapat dicegah dengan adanya latihan fisik dan stimulasi dini yang akan meningkatkan perkembangan pada anak. Stimulasi tumbuh kembang merupakan faktor yang memengaruhi perkembangan balita. Interaksi antara lingkungan dan stimulasi dapat memengaruhi perkembangan pada setiap anak. ${ }^{10}$

Berdasarkan uraian di atas dan adanya keterkaitan antara kejadian stunting, stimulasi tumbuh kembang dengan perkembangan balita, peneliti tertarik untuk melakukan penelitian hubungan status gizi dan stimulasi dengan perkembangan balita. Adapun tujuan penelitian ini adalah untuk menganalisis hubungan status gizi dan stimulasi tumbuh kembang dengan perkembangan balita di Provinsi Nusa Tenggara Barat (NTB).

\section{Metode}

Penelitian ini merupakan penelitian analitik observasional dengan desain cross-sectional. Penelitian dilakukan di Kabupaten Bima NTB pada bulan Februari - Maret 2018. Populasi penelitian adalah seluruh anak balita usia 12-60 bulan yang bertempat tinggal di wilayah kerja Puskesmas Soromandi Kabupaten Bima yang berjumlah 1759 balita.

Pengambilan sampel dengan menggunakan teknik simple random sampling. Diikutsertakan 114 subjek penelitian. Kriteria inklusi adalah anak balita usia 12-60 bulan yang bertempat tinggal di wilayah kerja Puskesmas Soromandi serta ibu dan anak bersedia menjadi subjek penelitian. Kriteria eksklusi adalah anak balita yang tidak tinggal bersama kedua orang tuanya dan anak balita dengan cacat fisik. Variabel bebas adalah status gizi dan stimulasi tumbuh kembang dan variabel terikat adalah perkembangan balita.

Pengumpulan data dilakukan dengan teknik wawancara berdasarkan kuesioner yang disusun berdasarkan pada stimulasi tumbuh kembang menurut usia yang terdapat dalam KPSP. Data yang diambil berdasarkan hasil penelitian dimasukkan ke dalam program perangkat lunak SPSS 22 untuk menganalisis dengan regresi logistik. 


\section{Hasil}

Karakteristik anak balita terdiri dari jenis kelamin, umur dan status gizi (TB/U). Distribusi frekuensi karakteristik subjek penelitian tertera pada Tabel 1 . Terdapat $57,9 \%$ subjek berjenis kelamin laki-laki dan 42,1\% perempuan. Berdasarkan kelompok umur terdapat sebagian besar umur anak balita berada pada kelompok umur 2536 bulan sebesar 35,08\%. Status gizi berdasarkan indeks tinggi badan menurut umur sebagian besar berada pada perawakan pendek (40,5\%). Karakteristik ibu berdasarkan pendidikan dan pekerjaan serta pendidikan ayah diketahui bahwa sebagian besar ibu berpendidikan tinggi $45(39,5 \%)$ orang. Sebagian besar ayah berpendidikan menengah 47 (41,2\%) orang. Karakteristik terakhir adalah pekerjaan ibu, sebagian besar ibu bekerja sebagai PNS/POLRI/TNI $41(35,0 \%)$ orang.

Pada Tabel 2 tertera analisis bivariat yang menunjukkan hubungan antara status gizi (TB/U) dan perkembangan balita. Didapatkan nilai $c h i-$ square hitung $\mathrm{p}=0,014$. Hal ini menunjukkan bahwa terdapat hubungan signifikan antara status gizi dan perkembangan anak. Analisis bivariat tentang hubungan antara stimulasi tumbuh kembang dan perkembangan anak didapatkan nilai chi-square hitung $\mathrm{p}=0,006$. Hal ini menunjukkan bahwa terdapat hubungan yang signifikan antara stimulasi tumbuh kembang dan perkembangan anak. Analisis multivariat menggunakan analisis regresi logistik pada tingkat kepercayaan 95\% $(\alpha=0,05)$. Hasil analisis regresi logistik antara variabel status gizi berdasarkan indeks tinggi badan menurut umur dan stimulasi dengan perkembangan pada anak balita.

Pada Tabel 3 tertera hasil uji hipotesis yang menunjukkan bahwa terdapat hubungan antara status gizi dengan perkembangan. Terdapat hubungan yang positif dan signifikan secara statistik. Anak balita yang memiliki status gizi dengan perawakan normal memiliki kemungkinan 3,3 kali untuk mempunyai perkembangan yang sesuai $(b=3,33 ; p=0,003)$.

Hasil uji hipotesis menunjukkan bahwa terdapat hubungan antara stimulasi tumbuh kembang dan perkembangan anak. Terdapat hubungan yang positif dan signifikan secara statistik. Anak balita yang stimulasi tumbuh kembangnya baik memiliki kemungkinan 3,1 kali untuk mempunyai perkembangan yang baik $(b=3,10 ; p=0,014)$.

\section{Pembahasan}

Hasil penelitian menunjukkan bahwa terdapat hubungan antara status gizi dan perkembangan anak. $\mathrm{Hal}$ tersebut sesuai dengan pendapat Soetjiningsih ${ }^{11}$ yang menjelaskan bahwa status gizi merupakan salah satu determina faktor perkembangan anak.Pada balita, aspek tumbuh kembang adalah salah satu aspek yang diperhatikan serius karena menjelaskan proses pembentukan seseorang, balita secara fisik maupun psikososial. Ranah perkembangan anak terdiri atas motorik kasar, motorik halus, bahasa dan bicara, serta personal sosial/ kemandirian. ${ }^{12}$

Masa tumbuh kembang balita sangat menentukan karena menjadi dasar terbentuknya manusia seutuhnya. Karena itu, pemerintah memandang perlu untuk memberikan suatu bentuk pelayanan penunjang

Tabel 1. Karakteristik subjek penelitian

\begin{tabular}{lcc}
\hline Variabel Karakteristik & $\begin{array}{c}\text { Frekuensi } \\
(\mathrm{n})\end{array}$ & $\begin{array}{c}\text { Persentase } \\
(\%)\end{array}$ \\
\hline Jenis kelamin & & \\
Laki-laki & 66 & 57,9 \\
Perempuan & 48 & 42,1 \\
Umur (bulan) & & \\
12-24 & 9 & 7,8 \\
25-36 & 40 & 35,1 \\
37-48 & 38 & 33,3 \\
49-60 & 27 & 18,7 \\
Status gizi (TB/U) & & \\
Sangat pendek & 28 & 24,6 \\
Pendek & 46 & 40,3 \\
Normal & 27 & 23,7 \\
Tinggi & 13 & 11,4 \\
Pendidikan ibu & & \\
Dasar & 45 & 39,5 \\
Menengah & 40 & 35,1 \\
Tinggi & 29 & 25,4 \\
Pendidikan ayah & & \\
Dasar & 31 & 27,2 \\
Menengah & 47 & 41,2 \\
Tinggi & 36 & 31,6 \\
Pekerjaan ibu & & \\
PNS/POLRI/TNI & 41 & 35,0 \\
Pegawai swasta & 11 & 9,6 \\
Wiraswasta & 39 & 34,2 \\
Petani/Nelayan & 23 & 20,2 \\
\hline & &
\end{tabular}


Mirham Nurul Hairunis dkk: Hubungan status gizi dan stimulasi tumbuh kembang dengan perkembangan balita

Tabel 2. Analisis bivariat hubungan status gizi (TB/U) dan stimulasi tumbuh kembang dengan perkembangan

\begin{tabular}{|c|c|c|c|c|}
\hline \multirow{3}{*}{ Status gizi $\mathrm{TB} / \mathrm{U}$} & \multicolumn{4}{|c|}{ Perkembangan balita } \\
\hline & Menyimpang & Sesuai & Total & $\mathrm{p}$ \\
\hline & $\mathrm{n}(\%)$ & $\mathrm{n}(\%)$ & $\mathrm{n}(\%)$ & \\
\hline Sangat pendek & 20 & 11 & & \\
\hline Pendek & 30 & 16 & 46 & \\
\hline Normal & 5 & 21 & 26 & 0,014 \\
\hline Tinggi & 4 & 7 & 11 & \\
\hline \multicolumn{5}{|l|}{ Pemberian stimulasi } \\
\hline Jarang & 49 & 33 & 82 & 0,006 \\
\hline Sering & 10 & 22 & 32 & \\
\hline
\end{tabular}

Tabel 3. Analisis multivariat antara status gizi TB/U dan stimulasi tumbuh kembang dengan perkembangan

\begin{tabular}{lccc}
\hline Kategori & OR & $\begin{array}{c}\text { IK95\% } \\
\text { (Batas atas-batas bawah) }\end{array}$ & $\mathrm{p}$ \\
\hline Status gizi (TB/U) & 3,3 & $(1,49-7,46)$ & 0,003 \\
Stimulasi tumbuh kembang & 3,1 & $(1,25-7,65)$ & 0,014 \\
\hline
\end{tabular}

tumbuh kembang balita secara menyeluruh, terutama dalam aspek mental dan sosial. Pertumbuhan dan perkembangan saling mendukung satu sama lain. Perkembangan seorang anak tidak dapat maksimal tanpa dukungan. Seorang anak memerlukan perhatian khusus untuk optimalisasi tumbuh kembangnya. Optimalisasi perkembangan diperlukan seperti adanya interaksi anak dan orang tua, terutama peran ibu yang sangat bermanfaat bagi proses tumbuh kembang anak secara keseluruhan. Orang tua dapat segera mengenali kelainan proses tumbuh kembang anak sedini mungkin dan memberikan stimulasi yang menyeluruh, baik aspek fisik, mental, sosial dan kemandirian. ${ }^{?}$

Pada fase kehidupan anak terdapat fase pertumbuhan dan perkembangan. Tumbuh kembang anak sangat dipengaruhi oleh kecukupan nutrisi. Kebutuhan nutrisi anak yang tidak terpenuhi menyebabkan anak akan mengalami kelainan gizi. Akibatnya, anak menjadi mudah terserang penyakit, pasif, mudah letih, lesu, mengantuk, tidak dapat menerima pelajaran dengan baik yang menyebabkan prestasinya akan berkurang. ${ }^{11}$ Selain itu, kekurangan gizi pada balita merupakan salah satu masalah kesehatan yang bisa berdampak pada kematian. Faktor status gizi menjadi hal penting yang harus diperhatikan untuk membantu perkembangan anak, khususnya di masa balita. ${ }^{11,15}$

Perkembangan motorik dan bahasa sangat dipengaruhi oleh status gizi, status kesehatan, dan stimulasi gerak dan bahasa yang sesuai dengan masa perkembangannya. Gizi kurang akan menghambat laju perkembangan anak. Akibatnya, proporsi struktur tubuh menjadi tidak sesuai dengan usianya dan berimplikasi pada perkembangan aspek lain. Apabila anak balita mengalami kurang gizi akan berdampak pada keterbatasan pertumbuhan, rentan terhadap infeksi, dan peradangan kulit. Akhirnya, perkembangan anak yang meliputi kognitif, motorik, bahasa, dan keterampilannya akan terhambat dibandingkan dengan balita yang memiliki status gizi yang baik. ${ }^{11}$

Status gizi kurang akan memengaruhi perkembangan mental maupun sosial anak. Oleh karena itu, keduanya harus mendapat perhatian, baik dari pemerintah, masyarakat maupun orang tua. Salah satu indikator untuk melihat pertumbuhan fisik anak adalah dengan melihat status gizi anak. Sebagai alat ukur untuk mengetahui tingkat perkembangan seorang anak dengan menggunakan kartu menuju sehat (KMS). ${ }^{12}$

Prevalensi gizi kurang dan buruk yang tinggi berdampak pada terjadinya stunting pada balita. Tiga faktor utama penyebab gizi kurang, yaitu kualitas dari kuantitas konsumsi pangan yang buruk, pola asuh, dan akses fasilitas kesehatan yang tidak memadai. ${ }^{16}$ Faktor yang berkaitan dengan stunting, yaitu, status sosial ekonomi keluarga, pendidikan orang tua, status gizi, berat badan saat lahir, penyakit anak, persediaan air bersih, pelayanan kesehatan, dan etnis. ${ }^{17}$ 
Hasil penelitian menunjukkan bahwa terdapat hubungan antara stimulasi tumbuh kembang dan perkembangan anak. Hal tersebut sesuai dengan pendapat Siti ${ }^{19}$ yang menjelaskan bahwa stimulasi tumbuh kembang merupakan salah satu faktor yang memengaruhi perkembangan anak. Stimulasi adalah perangsangan yang datang dari lingkungan luar individu anak. Stimulasi perkembangan merupakan hal yang sangat penting dalam tumbuh kembang anak dan merupakan cikal bakal proses pembelajaran anak yang berupa mendidik dan melatih. Anak yang mendapat stimulasi terarah dan teratur akan lebih cepat berkembang dibandingkan dengan anak yang kurang mendapatkan stimulasi. ${ }^{17}$

Tujuan tindakan memberikan stimulasi pada anak adalah untuk membantu anak mencapai tingkat perkembangan yang optimal atau sesuai yang diharapkan. Tindakan ini meliputi berbagai aktivitas untuk merangsang perkembangan anak, seperti latihan gerak, bicara, berfikir, kemandirian, dan sosialisasi. Stimulasi dilakukan oleh orang tua (keluarga) setiap ada kesempatan atau sehari-hari. Stimulasi disesuaikan dengan umur dan prinsip stimulasi. ${ }^{15}$

Lindawati ${ }^{14}$ juga menjelaskan bahwa terdapat beberapa faktor yang dapat memengaruhi laju perkembangan, di antaranya adalah faktor genetik, status gizi, pertumbuhan fisik, lingkungan, dorongan, motivasi orang tua, dan stimulasi. Stimulasi atau rangsangan terhadap anak untuk memperkenalkan suatu pengetahuan ataupun keterampilan baru ternyata sangat penting dalam peningkatan kecerdasan anak. Salah satu bentuk kecerdasan yang harus dikembangkan adalah stimulasi motorik karena perkembangan motorik anak pada usia balita mengalami perkembangan yang pesat, terutama motorik kasar. Malnutrisi dan stimulasi yang tidak memadai diidentifikasi sebagai faktor risiko utama terhadap perkembangan. Hal tersebut sesuai dengan hasil penelitian, selain faktor stimulasi tumbuh kembang, faktor status gizi juga berpengaruh terhdap perkembangan anak balita. Perkembangan anak yang dipengaruhi status gizi dan stimulasi tumbuh kembang, antara lain, perkembangan keterampilan kognitif, motorik, perilaku sosial, prestasi sekolah, serta pengembangan psikomotor. ${ }^{18}$

Stimulasi tumbuh kembang pada balita dipengaruhi oleh banyak faktor, salah satunya adalah pendidikan ibu. Pendidikan ibu menjadi salah satu faktor yang memengaruhi stimulasi tumbuh kembang. Pengetahun ibu terkait stimulasi dan pengetahuan tentang pertumbuhan balita sangat penting. Hal tersebut akan berpengaruh terhadap upaya ibu untuk mencegah gangguan perkembangan secara dini. Pendidikan formal orang tua yang rendah dapat meningkatkan proporsi gangguan perkembangan dan stunting. Ibu yang memiliki pendidikan baik berkesempatan memiliki pekerjaan baik. Dengan demikian dapat meningkatkan pendapatan. Selain itu, ibu akan mempunyai pengetahuan tentang kesehatan dan pola asuh balita yang baik, serta akan lebih memanfaatkan pelayanan kesehatan guna meningkatkan kesehatan anak. ${ }^{20}$

Pemberian stimulasi akan efektif apabila memperhatikan kebutuhan anak sesuai tahapan perkembangannya. Gabungan antara interaksi ibu dan anak yang positif, latihan fisik, dan stimulasi dini akan meningkatkan perkembangan anak. Stimulasi tumbuh kembang merupakan faktor yang memengaruhi perkembangan balita. Interaksi antara lingkungan dan stimulasi dapat memengaruhi perkembangan pada anak. ${ }^{8}$

Berdasarkan hasil penelitian dapat disimpulkan bahwa terdapat hubungan secara langsung status gizi yang normal dan stimulasi tumbuh kembang yang baik dengan perkembangan anak.

Keterbatasan penelitian ini adalah terdapatnya faktor lain yang dapat memengaruhi perkembangan balita selain status gizi dan stimulasi tumbuh kembang yang tidak disajikan pada penelitian ini. Saran untuk peneliti lain adalah dapat mengembangkan penelitan ini dengan mengkaji faktor lain yang dapat memengaruhi perkembangan pada balita dan dengan menggunakan metode case control.

\section{Kesimpulan}

Anak balita yang status gizi $(\mathrm{TB} / \mathrm{U})$ yang baik memiliki peluang 3,3 kali mengalami perkembangan yang sesuai. Anak balita yang sering mendapatkan stimulasi tumbuh kembang memiliki peluang 3,1 kali mengalami perkembangan yang sesuai.

\section{Daftar pustaka}

1. Gunawan SG. Farmakologi dan terapi. Edisi ke-5. Jakarta: FK Universitas Indonesia 2011: 230-46.

2. Sujiono. Metode pengembangan fisik. Jakarta: Universitas 
Terbuka, 2008.

3. Departemen Kesehatan RI. Pedoman pelaksanaan stimulasi. deteksi dan intervensi dini tumbuh kembang anak di tingkat pelayanan kesehatan dasar. Jakarta : Depkes RI; 2009.

4. Grantham S, Cheung YB, Cueto S, Glewwe P, Richter L, Strupp B. Development potential in the first 5 years for children in developping countries. Lancet 2007;369:60-70.

5. Departemen Kesehatan RI. Buku Kesehatan Ibu dan Anak Gerakan Nasional Pemantauan Tumbuh Kembang Anak. Jakarta: Departemen Kesehatan RI; 2008.

6. WHO. Nutrition landscape information system (NLIS) country profile indicators: interpretation guide. Geneva: WHO; 2011.

7. Dinas Kesehatan Provinsi Nusa Tenggara Barat. Profil Kesehatan Provinsi Nusa Tenggara Barat Tahun 2011. Mataram: Dinkes Prov NTB; 2012.

8. Chiarello LA, Palisano RJ. Investigation of the effects of a model of physical therapy on motherchild interactions and the motor behaviors of children with motor delay. Phys Ther 2008;78;2:180-94.

9. Departemen Kesehatan RI. Pedoman pelaksanaan stimulasi. Deteksi dan intervensi dini tumbuh kembang anak di tingkat pelayanan kesehatan dasar. Jakarta: Depkes RI; 2009.

10. Arianto SM. Diseminasi informasi: strategi pengelolaan local content. Seminar nasional diseminasi informasi local content: peluang dan tantangan dari sudut pandang cyberlaw. Diakses pada 12 Oktober 2018. Didapat dari: http://www.academia. edu/35898735/Diseminasi_Informasi_Strategi_Pengelolaan_ Local_Content1.
11. Soetjiningsih. Tumbuh kembang anak. Jakarta: ECG. Penerbit Buku Kedokteran; 2010.

12. Kementrian Kesehatan RI. Laporan hasil riset kesehatan dasar (Riskesdas) Tahun 2013. Jakarta: Kemenkes RI; 2013.

13. Roba AC. Effects of phytate reduction on maize/bean blend infant food used in Southern Ethiopia, tesis. Oklahoma: Oklahoma State University, 2016.

14. Lindawati. Faktor-faktor yang berhubungan dengan perkembangan motorik anak usia prasekolah. Diakses pada 12 Oktober 2018. Didapat dari: https://www.poltekkesjakarta1. ac.idlfileldokumen/46JURNAL_LINDAWATI.pdf.

15. Suherman. Perkembangan anak. Jakarta: EGC; 2010.

16. Hendrayati, Amir A, Darmawati. Faktor yang memengaruhi kejadian wasting pada anak balita di Kecamatan Marioriwawo Kabupaten Soppeng. Media Gizi Pangan 2013;15:56-61.

17. Mgongo M, Katanga J, Uriyo JG, Damian DJ, Stray-Pedersen $\mathrm{B}$, dkk. Predictors of appropriate breastfeeding knowledge among pregnant women in Moshi Urban, Tanzania: a crosssectional study. Int Breastfeeding J 2017;11:1-8.

18. Selina L, Pamela D, Richard H. Lancet early childhood development series steering committee. A good start will ensure sustainable future for all. Lancet 2017;389:8-9.

19. Siti SN, Fadillah N, Hasyim A, Hidayat. Perkembangan motorik kasar bayi melalui stimulasi ibu di Kelurahan Kemayoran Surabaya. Jurnal Sumber Daya Manusia Kesehatan 2014;1:1.

20. Pei L, Ren L, Yan H. A Survey of undernutrition in children under three years of age in rural Western China. Bio Med Central Pub Health 2014;14:121. 